\title{
The use of Annona squamosa seed, leaf and bark as an alternative in the control of
}

\section{Cryptotermes brevis}

O uso de semente, folha e casca de Annona squamosa como uma alternativa no controle de

\section{Cryptotermes brevis}

El uso de semillas, hojas y corteza de Annona squamosa como alternativa en el control de

\section{Cryptotermes brevis}

Kevyn Danuway Oliveira Alves

ORCID: https://orcid.org/0000-0002-8794-1094 Universidade do Estado do Rio Grande do Norte, Brazil

E-mail: kevynalves@alu.uern.br

Ana Carolyna Diógenes Bezerra

ORCID: https://orcid.org/0000-0001-8206-0629

Universidade do Estado do Rio Grande do Norte, Brazil E-mail: anacarolyna2000@gmail.com

Genizia Borges de Lima

ORCID: https://orcid.org/0000-0002-8123-425X Faculdade do complexo Educacional Santo André, Brazil E-mail: enfgenizialima@gmail.com

Fracisco Sérvulo de Oliveira Carvalho ORCID: https://orcid.org/0000-0002-3844-0461 Universidade Federal Rural do Semi-árido, Brazil E-mail: fservulo.ocarvalho@gmail.com

Ana Karolinne de Alencar França ORCID: https://orcid.org/0000-0001-6976-754X Universidade Federal Rural do Semi-árido, Brazil E-mail: karol_alencarf@hotmail.com João Matheus Caé da Rocha ORCID: https://orcid.org/0000-0002-4109-4598 Faculdade Nova Esperança de Mossoró, Brazil E-mail: j.matheus6@gmail.com

Sara Caroline Dantas Nunes

ORCID: https://orcid.org/0000-0001-5387-8739

Universidade Federal Rural do Semi-árido, Brazil E-mail: saracarolinecdn@gmail.com

Jessica Costa De Oliveira

ORCID: https://orcid.org/0000-0002-7905-1235 Faculdade do complexo Educacional Santo André, Brazil

E-mail: jessicacosta@ faculdadecesa.edu.br

Ismael Vinicius de Oliveira ORCID: https://orcid.org/0000-0001-9489-4081 Universidade Federal Rural do Semi-árido, Brazil E-mail: ismael.oliveira66277@alunos.ufersa.edu.br

Ana Carla Diógenes Suassuna Bezerra

ORCID: https://orcid.org/0000-0002-1039-5187

Universidade Federal Rural do Semi-árido, Brazil E-mail: anacarla@ufersa.edu.br

\begin{abstract}
The changes in human behavior towards the environment, the disorderly urban development, globalization and climate change are some of the factors that promote the occurrence and spread of pests that somehow bring damage. This occurrence is aimed at termites, which are insects known for their habit of feeding on cellulose, that is, papers, books, and wooden structures, causing accidents. Cryptotermes brevis are a major cause of damage to various wood species commonly used throughout the country, which cause major public health problems. Annonaceae have been extensively investigated because they present many species as a source of insecticidal compounds with different modes of action on insects. Therefore, this work aims to develop a natural, economical and sustainable product by using the extracts of the seeds of the fruit of the earl (Annona squamosa) as a resource to combat dry wood termites. From the results, it was possible to prove the veracity of the hypothesis that the natural
\end{abstract}


insecticides developed from the extract of the seeds of the fruit of the earl (Annona squamosa) are very efficient, and are effective in the issue of mortality rates of Cryptotermes brevis.

Keywords: Natural products; Arbovirus; Extract.

\section{Resumo}

As mudanças no comportamento humano em relação ao meio ambiente, a desordem do desenvolvimento urbano, a globalização e as mudanças climáticas são alguns dos fatores que promovem a ocorrência e propagação de pragas que de alguma forma trazem prejuizos. Esta ocorrência visa os cupins, que são insetos conhecidos pelo hábito de se alimentarem em de celulose, ou seja, papéis, livros, estruturas de madeira causando acidentes. Os cryptotermes brevis são uma das maiores causas de danos em várias espécies de madeira geralmente usadas em todo o país, os quais causam grandes problemas de saúde pública. Annonaceae tem sido bastante investigada por apresentar muitas espécies como fonte de compostos inseticidas com diferentes modos de ação sobre insetos. Portanto, O trabalho busca desenvolver um produto natural, econômico e sustentável por meio da utilização de extratos da semente da fruta do conde (Annona squamosa) como recurso de combate os cupins de madeira seca. A partir dos resultados, Foi possível comprovar a veracidade da hipótese, que os inseticidas naturais desenvolvidos do extrato da semente da fruta do conde (Annona squamosa) são bastante eficientes, e são eficazes na questão de índices de mortalidade do Cryptotermes brevis.

Palavras-chave: Produtos naturais; Arbovírus; Extrato.

\section{Resumen}

Los cambios en el comportamiento humano en relación con el medio ambiente, el desorden del desarrollo urbano, la globalización y el cambio climático son algunos de los factores que promueven la aparición y propagación de plagas que, de alguna manera, traen consigo daños. Esta ocurrencia está dirigida a las termitas, que son insectos conocidos por su hábito de alimentarse de la celulosa, es decir, papeles, libros, estructuras de madera, provocando accidentes. Los Cryptotermes brevis son una de las principales causas de daños en diversas especies de madera utilizadas habitualmente en todo el país, lo que provoca importantes problemas de salud pública. Las anonáceas han sido ampliamente investigadas porque presentan muchas especies como fuente de compuestos insecticidas con diferentes modos de acción sobre los insectos. Por lo tanto, este trabajo tiene como objetivo desarrollar un producto natural, económico y sostenible mediante el uso de extractos de las semillas del fruto del conejo (Annona squamosa) como recurso para combatir las termitas de la madera seca. A partir de los resultados, se pudo comprobar la veracidad de la hipótesis de que los insecticidas naturales desarrollados a partir del extracto de las semillas del fruto de la oreja (Annona squamosa) son muy eficientes, y son eficaces en la cuestión de la mortalidad de Cryptotermes brevis.

Palabras clave: Productos naturales; Arbovirus; Extracto.

\section{Introduction}

The use of synthetic insecticides has always been the main method of pest control. However, indiscriminate application for long periods can lead to the disposal, contamination, and accumulation of potentially toxic pollutants in the environment, resulting in serious undesirable effects on the ecosystem and public health (Nie et al., 2019). Therefore, control measures with less environmental impact are the most important, which has stimulated the resurgence of insecticidal plants as a promising insect control tool.

Annona squamosa belongs to the Annonaceae family, commonly known as the fruit of the earl. It is a beautiful family that deserves to be highlighted, as it is currently the most studied and used family for the alternative control of insect pests, being the acentogenins found in the barks of twigs, roots, and seeds of plants of this family (PAZ et al., 2018)

Pest insects, such as drywood termites Cryptotermes brevis, cause many problems. Due to the presence of microorganisms in their bodies, termites can break down any compound made of cellulose. Therefore, these termites are attracted to all cellulose-based materials, such as wood (dry wood), paper, cloth, etc. (ELECOTERIUM, 2000). When termites attack wood, long corridors are formed, causing damage, reducing the mechanical strength of this material. (Corassa, 2014).

Therefore, the work seeks to develop a natural, economical and sustainable product as a resource to combat dry wood termites through Annona squamosa. 


\section{Methodology}

The mortality of termites was tested using extracts of the seed, leaf and bark of the fruit of the earl (Annona squamosa). To prepare the extracts (aqueous and ethanolic), the plant parts used in the bioassays were collected at the coolest hours of the day, in Umarizal/RN. The fruit was peeled and the seeds and leaves were removed from the top of the plant, and then dried for 2 weeks.

To prepare the extracts, we used an acrylic glass with movable blades attached to the bottom, in which the harvested parts were crushed. The grinding was done in different amounts of solute, with equal amounts of solvent for the different extracts, 1 liter of water for aqueous extract, in all different extracts for leaves as well as fruits and seeds, and $500 \mathrm{ml}$ of alcohol for each different ethanolic extract.The aqueous material was left to rest for 24 hours as proposed by (EMBRAPA, 2006), in a place without incidence of light and the ethanolic extract was kept at rest for 120 hours for better extraction of the active ingredients (SANTOS et al, 2012). After the respective periods, the materials were strained and placed in containers. In the experiments there were 4 repetitions. It is worth mentioning that two experiments were performed for each control substance. In the first, the application was done indirectly and in the second, the extract was applied directly to the termite

For the experiment we used 4 containers to hold 40 dry wood termites (Cryptotermes brevis), we put 10 termites in each container. In these containers we put a piece of absorbent cotton and sawdust and in the middle 10 drops of the natural insecticide, and the control group was distilled water. For termite mortality test experiments was according to Cruz et al, (2012). In the second experiment, 20 dry wood termites and two well plates were used, 10 termites in each plate. In the first plate, the ten termites were distributed unitarily in each compartment and one drop of the distilled water-based extract was applied on each of the termites, and in the second container, one drop of distilled water was applied on each of the termites. The mortality/survival rate of drywood termites (Cryptotemes brevis) was observed.

In the experiment with ethanolic extract made with dry wood termites (Cryptotermes brevis) we used 4 containers to hold 40 termites. We put 10 termites in each container, and in these containers we put a piece of cotton and iron and in the middle 10 drops of the natural insecticide, and the control group was alcohol $46 \%$. In the second experiment, 20 dry wood termites and two well plates were used, 10 termites in each plate. In the first plate, the ten termites were distributed unitarily in each compartment and a drop of the ethanolic extract was applied on each of the termites, and in the second container, a drop of $46 \%$ alcohol was applied on each of the termites. The mortality/survival rate of drywood termites (Cryptotemes brevis) was observed.

\section{Results and Discussion}

Figure 1 represents the mortality rate in minutes with the test done with the ethanolic extract, Figure 2 represents the mortality rate in minutes done with the aqueous extract. 
Figure 1. Represents a direct application of insecticides on adult termites (Cryptotermes brevis).
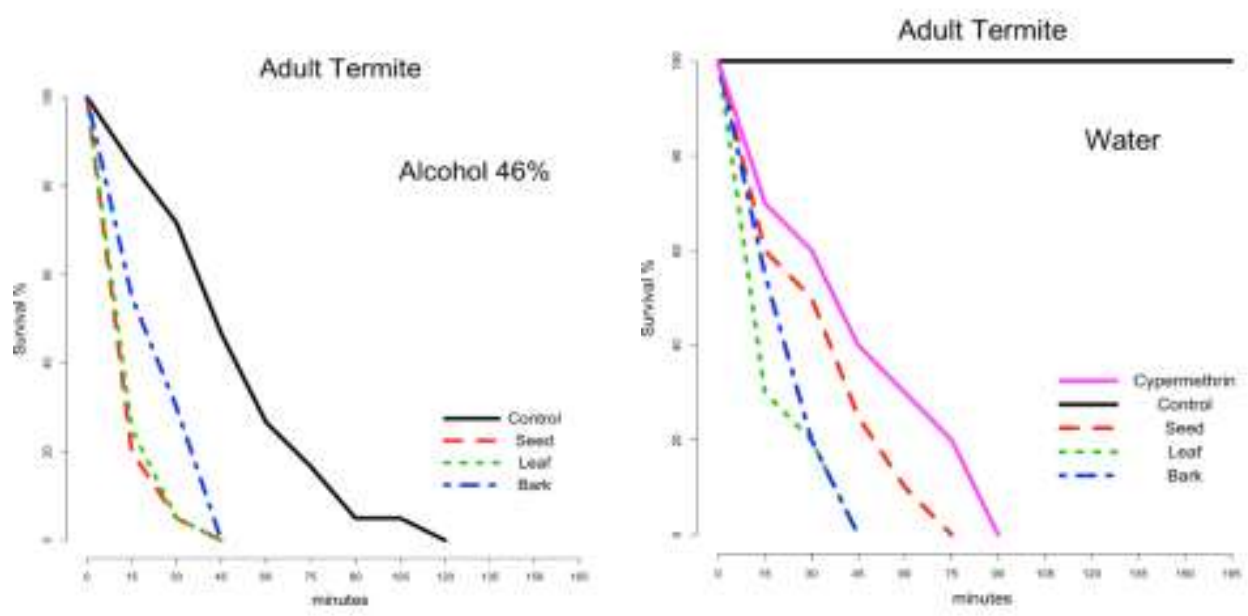

* Survival of Adult termites submitted to direct application of Sugar-Apple extracts dissolved in alcohol $46 \%$ and distilled water. Source: Authors.

Figure 2. Represents a indirect application of insecticides on adult termites (Cryptotermes brevis).
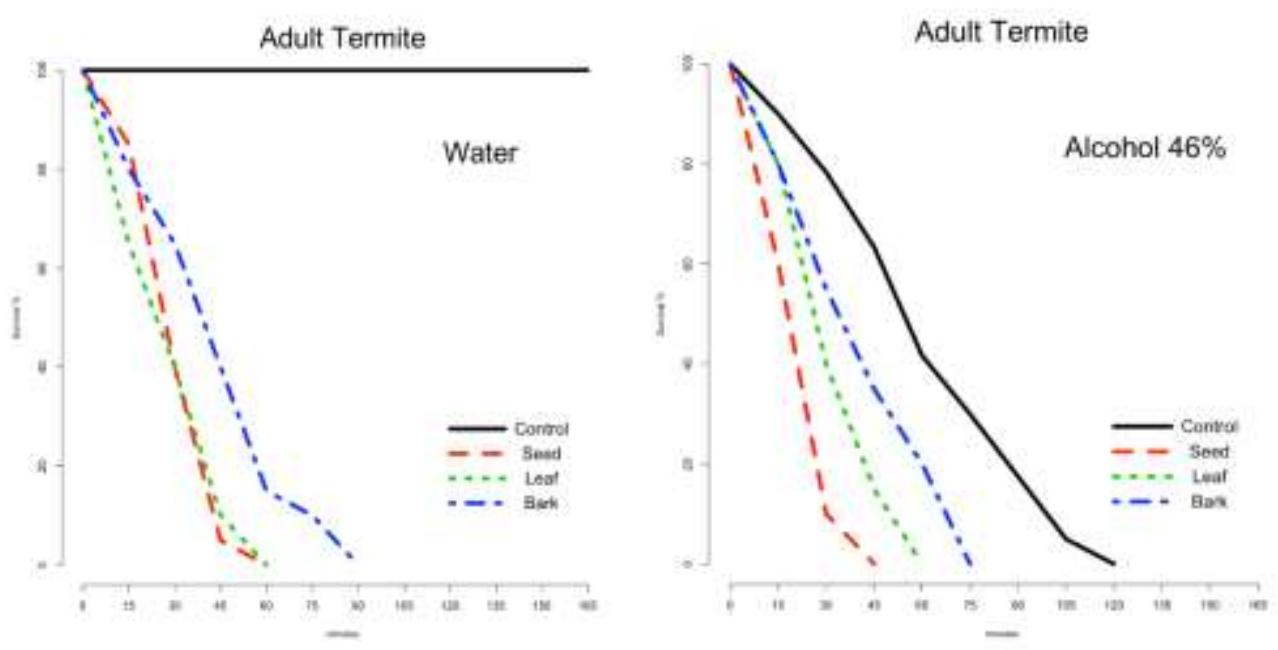

*Survival of adult termites submitted to indirect application of Sugar-Apple extracts dissolved in alcohol $46 \%$ and distilled water. Source: Authors.

Figures 01 and 02 show that the insecticides had an average mortality time on drywood termites (Cryptotermes brevis) with seeds of 56 minutes and 25 seconds, on bark 1 h03 minutes, and on leaves 52 minutes 50 seconds. Note that the seeds proved to be a potential insecticide and their mortality rate in time is much lower compared to the others.

From the results, it was possible to prove the veracity of the hypothesis, that the natural insecticides developed from the extract of the seeds of the fruit of the earl (Annona squamosa) are very efficient, indicating that they are more effective than the industries in the question of mortality rates of Cryptotermes brevis.

Proving that the fruit of the earl (Annona squamosa) also has the component acetogenins that constitute a class of natural products promising as prototypes of insecticidal agents, being found in the barks of branches and roots, roots and, especially, in seeds of plants of the Annonaceae family (Bermejo et al., 2005; Castillo-Sánchez et al., 2010). The insecticidal 
activity is due to the presence of the substance Acetogenins that acts in the mitochondria, inhibiting NADH - ubiquinone and oxidoreductase, causing the death of insects (Zafra-Polo et al., 1996; Lümmen, 1998).

\section{Conclusion}

The aqueous proved to be a better extractor of the active ingredients from the seed, leaf and bark of the Annona squamosa conde fruit, consequently, the aqueous extract proved to be more effective in combating dry wood termites (Cryptotemes brevis). The bioinsecticides made from seeds, leaf and bark extracts of pine cones (Annona squamosa) proved to be very efficient for dry wood termite control. The use of this natural insecticide is effective, bringing benefits to the population, since the natural insecticides based on pine cones (Annona squamosa) are naturally bioactive and present cytotoxic activity. The use of natural pesticides is an alternative when related to synthetic chemicals being used for the same purpose, because the product developed becomes more economical and accessible than synthetic pesticides, besides contributing to human health. Etudies tend to continue with tests with other insect pests to help the population to fight in an environmentally friendly and successful way.

\section{References}

Belmain, S. R., Neal, G. E., Ray, D. A. \& Golob, P. (2001) Insecticida e toxicidade de vertebrados associada a etnobotânicos utilizados como protectores pós-colheita no Gana. Toxicologia Química e Alimentar. 39, 287-91.

Bogorni, P. C. \& Vendramim, J. D. (2003). Bioatividade de extratos aquosos de Trichilia spp. sobre Spodoptera frugiperda (J.E. Smith) (Lepidoptera: Noctuidae) em milho. Neotrop. entomol., Londrina. 32, 665-9.

Brazolin, S., Fernandes, J. L. G., Lopes, G. A. C., Monteiro, M. B. B. \& Zenid, G. J. (2001) Biodeterioração de madeiras em edificações. São Paulo: IPT.

Constantino, R. (2002) The pest termites of South America: taxonomy, distribution and status. Journal of Applied Entomology, Hamburg, v. 126, p. 355-365.

Corassa, Janaína de Nadai, et al. (2014) Témitas Associados à Degradação de Cinco Espécies Florestais em Campo de Apodrecimento. Floresta e Ambiente: 21(1):78-84 79. Instituto de Ciências Agárias e Ambientais, Universidade Federal de Mato Grosso - UFMT, Sinop/MT, Brasil.

Cruz, C. S. A.; Medeiros, M. B.; Sousa, F. C.; Silva, L. M. M.; Gomes, J. P. (2012) Uso de Partes Vegetativas em Forma de Pó Seco no Controle de Cupins Nasutitermes sp. (Insecta: isoptera) termitidae. Revista Verde de Agroecologia e Desenvolvimento Sustentável, v. 7, n. 2, p.102-105.

Eleotério, Eliane Santos da Rocha; FILHO, Evôneo Berti.(2000) Levantamento e identificação de cupins (Insecta: Isoptera) Em área urbana de Piracicaba SP. Ciência Florestal, Santa Maria, v.10, n.1, p.125-139.

EMBRAPA. (2006) Uso do extrato aquoso de folhas de nim para o controle de Spodoptera frugiperda no milho. Sete Lagoas: Embrapa Milho e Sorgo. 5 p. (Embrapa Milho e Sorgo. Circular Técnica, 88).

Hernandez, C.R, Angel, D.N (1997) Anonaceas com propriedades inseticidas. Vitória da conquista: Universidade Estadual do Sudoeste da Bahia, pág. 229239.

Huang, Y.; Lam, S.L.; Ho, S. H. (2000) Bioactivies of essential oil from Ellateria cardamomum (L.) Maton. to Sitophilus zeamais Motschulsky and Tribolium castaneum (Herbst). Journal of Stored Products Research, v.36, p.107-117.

Instituto de pesquisas tecnológicas. (1980) Métodos de ensaios e análise em preservação de madeira: ensaio acelerado de laboratório da resistência natural ou de madeira preservada ao ataque de térmitas do gênero Cryptotermes (Fam. Kalotermitidae). São Paulo. 1 p. (Publicação IPT, 1157).

Lelis, A. T. (1976) Cupins: prevenção e erradicação. Preservação de Madeiras, v.6-7, n.1, p.51-58.

Lümmen, P. (1998) Complex I inhibitors as insecticides and acaricides. Biochimica et Biophysica Acta, Amsterdam, v. 1364, n.2, p.287-296.

Nie, J., Sun, Y., Zhou, Y., Kumar, M., Usman, M., Li, J., Shao, J., Wang, L. \& Tsang, D. C. W. (2019). Bioremediation of water containing pesticides by microalgae: mechanisms, methods, and prospects for future research. Science of The Total Environment, 707, 136080.

Oliveira, J. V.; Vendramim, J.D. (1999) Repelência de óleos essenciais e pós vegetais sobre adultos de Zabrotes subfasciatus (Boh.) (Coleoptera: Bruchidae) em sementes de feijoeiro. Anais da Sociedade Entomológica do Brasil, v.28, p.549-555.

Pontes, A. F.; Barbosa, M. R. V.; Maas, P. J. M. (2004) Flora Paraibana: Annonaceae Juss. Acta Botânica Brasílica, v.18, n.2, p.281-93.

Santos, A. V et al. et al. (2010) Efeito in vitro do extrato de nim (Azadirachta indica) e óleo essencial de cravo (Syzygium aromaticum) sobre Rhipicephalus (Boophilus) microplus*. Revista brasileira de medicina veterinária., 111-115. 
Research, Society and Development, v. 10, n. 12, e204101220307, 2021

(CC BY 4.0) | ISSN 2525-3409 | DOI: http://dx.doi.org/10.33448/rsd-v10i12.20307

Silva, J. C.; Lopez, A. G. C.; Oliveira, J. T. S. (2004) Influência da idade na resistência natural da madeira de Eucalyptus grandis W. Hill ex. Maiden ao ataque de cupim de madeira seca (Cryptotermes brevis). Revista Árvore, Viçosa, v. 28, n. 4, p. 583-587.

Soerjato, D. D. (1996) Biodiversity prospecting and beneficit sharing: perspective from field. Journal of Ethnopharmacology, v.51, p.1-15. 